\title{
Water Dynamics of the Sefrou Watershed, Northern Tabular Middle Atlas, Morocco
}

\author{
Farah El Hassani ${ }^{*}$, Youssef Hattafi ${ }^{2}$, Abderrahim Lahrach ${ }^{2}$ \\ ${ }^{1}$ Department of Environment, Engineering Faculty, The Euromed University of Fez, Fez, Morocco \\ ${ }^{2}$ Department of Environment, Faculty of Science and Technology, Sidi Mohammed Ben Abdellah University of Fez, Fez, Morocco \\ Email: ^f.elhassani@ueuromed.org
}

How to cite this paper: El Hassani, F., Hattafi, Y., \& Lahrach, A. (2021). Water Dynamics of the Sefrou Watershed, Northern Tabular Middle Atlas, Morocco. Journal of Geoscience and Environment Protection, 9, 102-130.

https://doi.org/10.4236/gep.2021.99007

Received: July 31, 2021

Accepted: September 25, 2021

Published: September 28, 2021

Copyright $\odot 2021$ by author(s) and Scientific Research Publishing Inc. This work is licensed under the Creative Commons Attribution International License (CC BY 4.0).

http://creativecommons.org/licenses/by/4.0/

\begin{abstract}
The Sefrou watershed, located in the northern part of the Tabular Middle Atlas, is the primary watershed in the Sebou region. Due to increasing socio-economic development, the need for a stable water supply is critical. Therefore, this watershed's physiography and morphology are studied to aim and facilitate further research in the Sebou region. We rely on the hydrological regime, frequency analysis of extreme flows, rainfall volume, and flood periods forecast to enable that characterization. Our findings determined that the Sebou region is of pluvial type with abundant rainfall, especially in winters due to floods. Moreover, substratum parameters induce a large volume of water resources from upstream to downstream. However, the weak structure of the hydrographic network and the water balance has highlighted a considerable loss of these resources, which handicaps the irrigation system and the supply of drinking water to the region's cities. Finally, the annual modulus and the different coefficients show hydroclimatic fluctuations of semi-arid climatic conditions, with a temperate winter. Our results suggest a need to monitor water runoff and protect surface soils from flooding and rapid erosion (by planting trees). We also propose installing barriers and a small dam to recharge groundwater and artificially store surface water in this watershed.
\end{abstract}

\section{Keywords}

Middle Atlas, Sebou, Sefrou Watershed, Basin Morphology, Water Resources

\section{Introduction}

Morocco is subject to various climatic conditions that vary from north to south due to its latitude and west to east due to its heterogeneous topography (Beaudet, 1969; Marchane et al., 2021). As a result, rainfall is highly irregular, especially in the Atlas Mountains. The precipitation and the consequent flows of the 
rivers of the Sebou river basin in the north of Morocco have shown significant climatic fluctuations with an irregular but cyclic trend of about 8 to 12 years (Bouabid \& Chafai Elalaoui, 2010; Singla et al., 2010). Adaptation to this phenomenon requires implementing mechanisms and actions to recognize, preserve, and safeguard water resources.

The Sebou basin has been studied in its northern part (Ouergha watershed; Msatef et al., 2018) and also in the southeast (Haut Sebou watershed; Qadem, 2015), and its western part (Sefrou watershed) remains to be characterized.

In this paper, we focus on studying the Sefrou region, an essential component of the southeastern part of the Great Sebou Basin (primary rainfall receiver in northern Morocco; Agoumi \& Debbarh, 2006), more specifically, the region's primary watershed. Our choice is due to the ever-increasing socio-economic development that the region experiences. Such development implies a significant increase in water needs and supply for agriculture, industry, and drinking water in the future. Therefore, data collection and processing are necessary to accommodate the increase in water demand in the region.

The study we present here concentrates on the characteristics of the overall water dynamics of this watershed. Thus, our study will enable data-driven decision-making that will, in turn, facilitate the sustainable development of the Sefrou region. To achieve that goal, we propose a physical characterization analysis of the Sefrou watershed in addition to topographic, morphological, hydrographic, and climatic characterization studies of the studied region using Geographic Information Systems (GIS). The processed data is fundamental to the evaluation of water resources. Furthermore, it will enable the analysis of the watershed's behavior and monitor its hydrological response.

\section{Materials and Methods}

\subsection{Data Acquisition}

The climate data used in this paper are spreading over a reasonable period (more than 60 years, for temperature and precipitation). Also, the physical data come from fieldwork over four years (2016 to 2020) and their processing in the laboratory by different methods (ArcGis, DTM, ...). We carried out the hydroclimatic data from five stations of the Sefrou watershed: Ain Timedrine, Sefrou, Azzaba, ABHS-Fez, and Allal Elfassi Dam, data made available by the Sebou River Basin Agency (ABHS). They allow us to examine the watershed variables (precipitation, temperature, aridity) and make graphical representations to understand better this watershed's functioning (maps and curves). We can see the geographical coordinates of these stations are as follows (Table 1).

\subsection{Methods}

Our approach to the study and characterize the Sefrou watershed consists in analyzing the data from four perspectives:

- physical characteristics and geometry, 
Table 1. Lambert coordinates ( $X, Y$ and $Z$ ) of surveyed stations.

\begin{tabular}{ccccc}
\hline Station & Station number & $X$ & $Y$ & $Z$ \\
\hline Ain Timedrine & 576 & 578,700 & 350,350 & 650 \\
Sefrou & 6562 & 549,370 & 359,200 & 930 \\
Azzaba & 1496 & 569,650 & 359,570 & 478 \\
ABHS-Fez & 3817 & 535,400 & 384,800 & 415 \\
Allal Elfassi Dam & 876 & 566,650 & 370,540 & 430
\end{tabular}

- Physiographic characteristics,

- Climatic context,

- Hydrological network.

\subsubsection{Geographical and Geological Presentation of the Sefrou Watershed}

The Sefrou watershed is located between the parallels $\left(33.41^{\circ}\right.$ to $\left.34^{\circ} \mathrm{N}\right)$ and meridians $\left(4.43^{\circ}\right.$ to $\left.4.56^{\circ} \mathrm{W}\right)$. This area crosses two vital rivers, which take Aggay River (south of Sefrou) and then El Yhoudi River (north of the Sefrou), as seen in Figure 1. In its downstream part, this watershed covers an area close to 405 $\mathrm{km}^{2}$ with a perimeter of $127.42 \mathrm{~km}$. The main watercourse comes from mountainous sources: the latter funnels water through the tabular Middle Atlas via Sefrou. The water flow will continue towards the El Yhoudi River's upstream, ending up in the Sebou River, crossing different geographical regions and bioclimatic environments (Benaabidate, 2000).

The geographical and geological aspects show that this watershed is part of the Atlas mountain that extend over $2000 \mathrm{~km}$ between the Moroccan Atlantic margin in the west and Tunisia in the east. Major lineaments bound this system called southern and northern Atlas faults, with adjacent sub-atlasic depressions subdivided within Morocco into the Middle and High Atlas.

The geological data show that this watershed is positioned on the NE part of the Tabular Middle Atlas and the Saiss plain (Termier, 1936; Termier \& Dubar, 1940; Martin, 1981; Benshili, 1989; Cirac, 1987; Charrière, 1984, 1989, 1992; Fedan, 1988; Ahmamou, 1987; Fedan \& El Hassani, 2018). The stratigraphic series of this area are subdivided into four groups (Figure 2).

A Paleozoic basement, Ordovician to the Carboniferous, is particularly characterized by a complete Devonian sequence of conglomerates, limestones, reef limestones, and carbonate marls (Aboussalam et al., 2020).

The post-Paleozoic cover consists of an Upper Triassic clay-evaporite series (gypsiferous clay and mixed basalts); followed by Kandar Dolomitic Formation of Sebkha's environment (Charrière, 1992) of lower Liasic age dolomitic deposits. Then brecciated dolomites, dolomitic sands, and bedded dolomites; The Liasic series continues with massive limestones with Oncolites, Gastropods, Terebratula, and imperforate foraminifera, and finally, oolite limestones with reefs 
that show frequent dolomitization (El Hammichi et al., 2008, 2016).

After major unconformity, above the Jurassic series, the northern outcrop of Sefrou (in the Sais plain and its borders) contains marl formations that fill the basin (Ahmamou, 1987).

This stratigraphic sequence ends with the Sais's lacustrine limestones (middle to upper Pliocene), and finally, the Quaternary Formations (travertines, crusts, alluviums, glacis, and terraces (Gourari, 2001).

\subsubsection{Land Use in the Sefrou Watershed}

Vegetation activity and soil type are intimately linked, and their combined actions have a significant influence on surface runoff. The vegetation cover retains a variable proportion of atmospheric water, depending on its density, nature, and the amount of precipitation. As a result, the intercepted water is partially removed from the runoff. The forest plays an essential role in the retention of this water. An index $(K)$ characterizes this retention (in \%) and corresponds to the forest area's ratio to the watershed area.

We calculate the forest cover index $(K)$ from the obtained vegetation map of the Sefrou watershed (Figure 3). In this case: $K=($ forest area/watershed area) $=$ $4.8304 / 405=1.08 \%$. This indicates that this watershed has a weak vegetation.

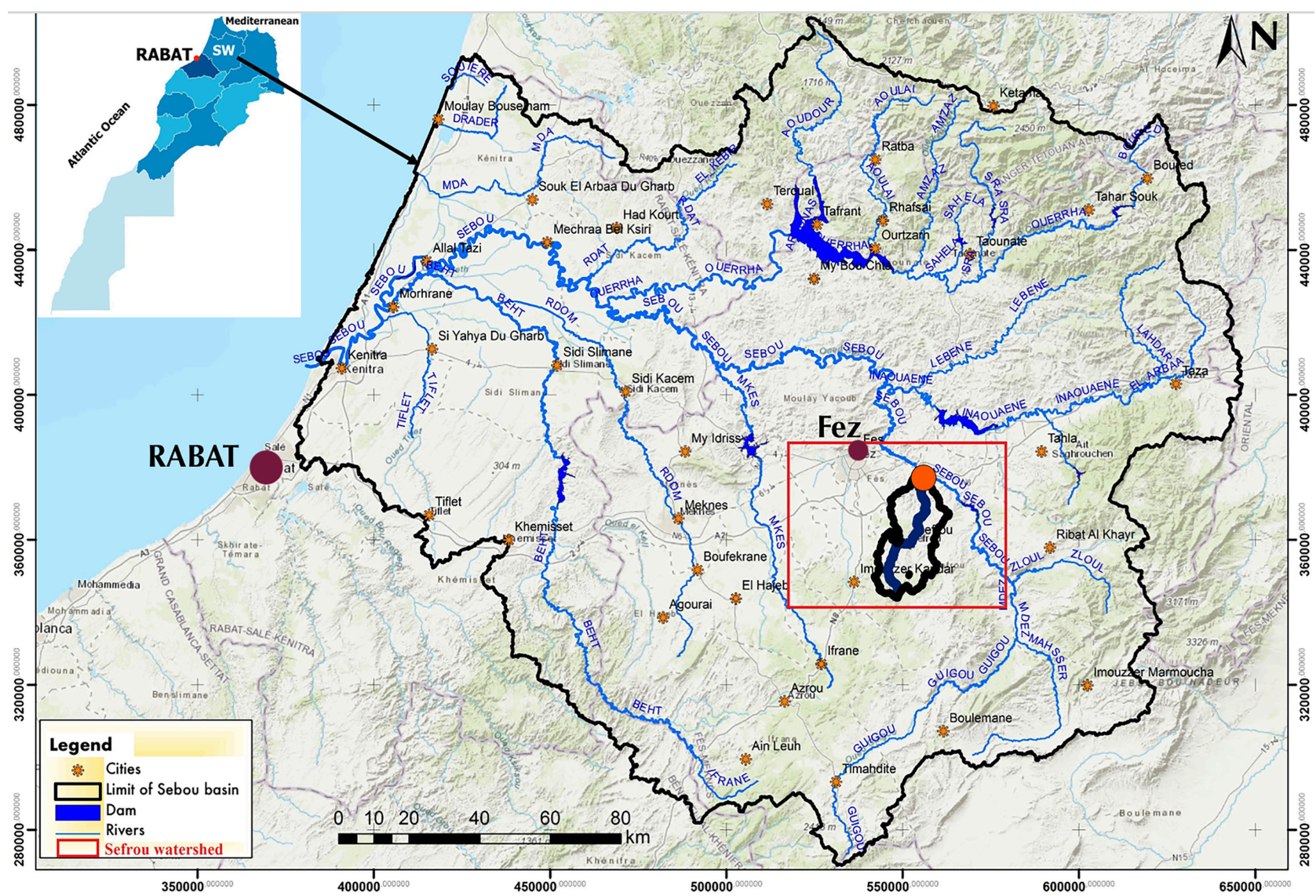

Figure 1. Position of the Sefrou watershed within the large Sebou basin (SW). The orange point represents the meteorological station of Ain Elouali, located at the outlet of the Sefrou principal stream. 


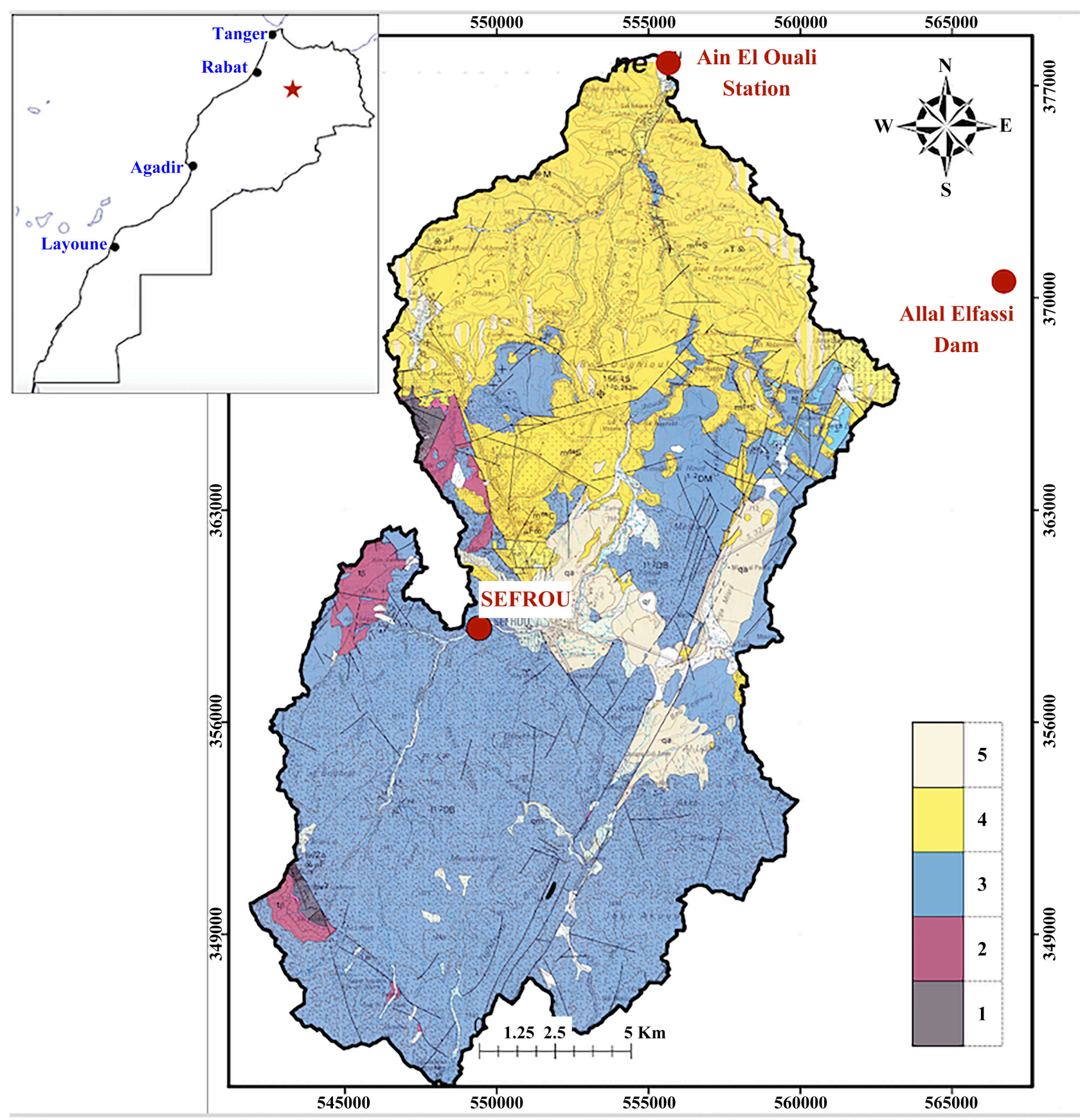

Figure 2. Location of the studied area and geological map of the Sefrou watershed (from Charriere, 1989). 1. Paleozoic; 2. Triasic; 3. Jurassic; 4. Miocene; 5. Pliocene and Quaternary.

\subsubsection{Physical Characteristics and Geometry of the Watershed}

We describe the physical characteristics of the Sefrou watershed and its geometry (area, morphology, shape, topography, relief) through the general data. Knowledge of the geological context and configuration of the watershed are crucial elements to understand surface and underground flow mechanisms, considering that the quality of the substrate influences not only the groundwater flow but also the surface flow. Moreover, it helps to determine the bedrock's permeability and explain its influence on the differentiation of the hydrogeological context. 


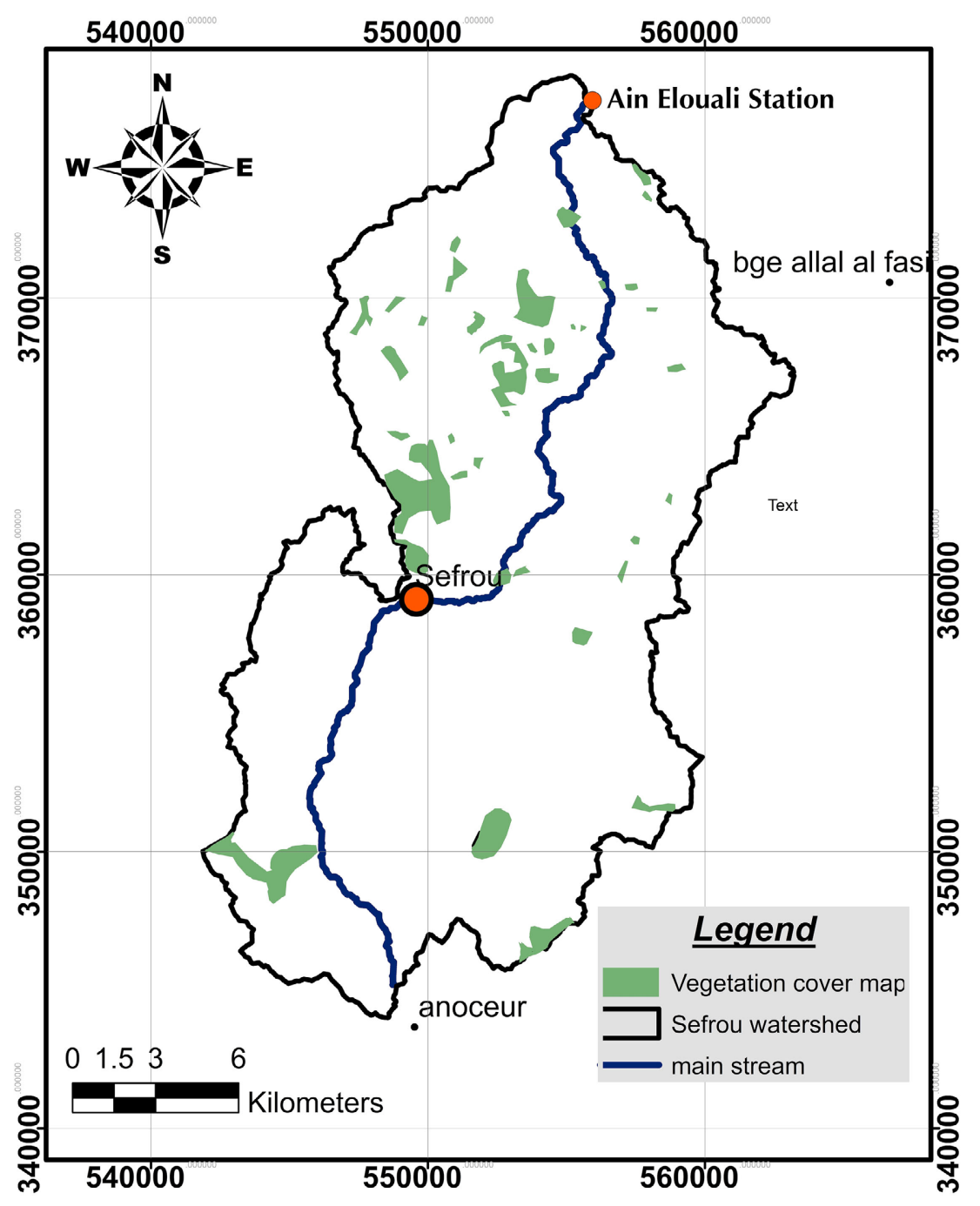

Figure 3. Vegetation map of the Sefrou watershed.

The resulting data from this step will enable determining its morphology, interactions with meteorological phenomena, and hydrological behavior. Furthermore, Hydroclimatic indicators (i.e., precipitation, temperature, vegetation, runoff) are necessary to measure the influence of relief on the watershed function; we will focus on:

- Hypsometric curve: To better understand the variations in altitude within the Sefrou watershed, and to translate the distribution of altitudes within the study area. We calculate the average altitude $\left(H_{\text {avg }}\right)$ using the following equation:

$$
H_{\text {avg }}=\sum_{i=0}^{N} \frac{A_{i} \times h_{i}}{A}
$$

where: $A_{i}$ : Area between two contour lines $\left(\mathrm{km}^{2}\right)$ per observation; $h_{i}$ : Average altitude between two contour lines (m) per observation; $A$ : Total area of the watershed $\left(\mathrm{km}^{2}\right)$, and $N$ : Total number of observation.

The median altitude is the value found at $50 \%$ of the total watershed area. 
Odd numbers:

$$
H_{\text {Med }}=\left|\frac{N+1}{2}\right|^{\text {th }} \text { observation }
$$

Even numbers:

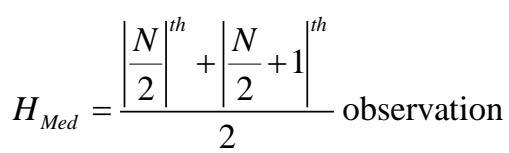

- Concentration time is defined as the time needed for water to flow from the most remote point in a watershed to the watershed outlet (Haan et al., 1994).

The time concentration-time of water is not only a function of the shape of the basin but also of other parameters:

- lithology (permeable formations favor infiltration at the expense of runoff, which delays the concentration of water at the outlet),

- rainfall (the higher the rainfall intensity, the shorter the concentration-time, regardless of the soil type),

- And relief.

There are several formulas for its calculation. To achieve the latter, we use the formula of Giandotti (1937):

$$
T_{c}=\frac{4 \sqrt{A}+1.5 \times L}{0.8 \sqrt{H_{\text {avg }}}}
$$

where: $T_{c}$ : concentration-time (hours); $A$ : area of the watershed $\left(\mathrm{km}^{2}\right) ; L$ : length of the main thalweg watercourse $(\mathrm{km}) ; H_{\text {avg: }}$ average altitude $(\mathrm{m})$.

- The global slope index Ig (in $\mathrm{m} / \mathrm{km}$ ) allows the assessment of the basin's relief importance. We define it as the ratio between the useful drop $\left(D_{u}\right)$ and the length $(L)$ of the equivalent rectangle, using the following equation:

$$
I_{g}=\frac{D_{u}}{L_{e q}}=\frac{H_{5 \%}-H_{95 \%}}{L_{e q}}
$$

where: $H_{5 \%}$ : altitude which corresponds to $5 \%$ of the cumulated surface; $H_{95 \%}$ : altitude which corresponds to $95 \%$ of the cumulated surface; $D_{u}$ : Difference in altitude $H_{5 \%}-H_{95 \%}$; and $L_{e q}$ : length of the equivalent rectangle (km).

\subsubsection{Physiographic Characteristics}

We approach the specific physiographic characteristics of the Sefrou watershed thanks to the different morphological indices (Gravelius compactness index, Horton compactness index).

Gravilius's compactness index $\left(K_{c}\right)$ : According to Roche (1963), the index used by hydrologists to characterize the watershed shape is Gravilius's compactness index (Gravelius, 1914). We calculate Gravilius's compactness index by dividing the perimeter of the watershed by that of a circle of the same area.

$$
K_{c}=\frac{P}{2 \sqrt{\pi A}}=0.28 \frac{P}{\sqrt{A}}
$$

where: $K_{\dot{c}}$ Gravilius's compactness index; $A$ : watershed surface $\left(\mathrm{km}^{2}\right)$; and $P$ : Pe- 
rimeter of the watershed $(\mathrm{km})$.

Horton's compactness index (Horton, 1932) provides information on the geometry of the watershed. We calculate it by dividing the average width of the watershed by the length of the mainstream, using the following equation:

$$
K_{h}=\frac{W_{a v g}}{L^{2}}
$$

where: $K_{h}$ : Horton's compactness index; $W_{\text {avg: }}$ average width of the watershed $(\mathrm{km})$; and $L$ : length of the mainstream $(\mathrm{km})$.

\subsubsection{Climatic Context}

We focus on studying the climatic context, necessary for the understanding of the supply mechanisms and circulation of surface water (rainfall, potential evapotranspiration, actual evapotranspiration, and amount assessment of the water falling). Furthermore, we develop hydrographic network characteristics (drainage density, torrentiality coefficient, network hierarchy, longitudinal profile of the watershed). Evapotranspiration is an essential component in water balance and irrigation scheduling models (Fisher \& Pringle III, 2013).

Potential evapotranspiration ( $P E T$, expressed in $\mathrm{mm}$ ) is a concept defined by Thornthwaite and Mather (1955); it expresses the quantity of water that would evaporate from the soil and be transpired by the vegetation if there were no water supply problems. It is therefore independent of the actual water availability of the soil. It depends only on the capacity of the ambient atmospheric environment to induce evapotranspiration and thus mainly involves energy indicators.

Actual evapotranspiration ( $A E T$, expressed in $\mathrm{mm}$ ) is the amount of water evaporating from the soil/substrate and plants when the soil is at its natural moisture content. Actual evapotranspiration explains water and energy exchange between the soil, the land surface, and the atmosphere. Thus, actual evapotranspiration is a significant component of the hydrological cycle and an essential physical process in natural ecosystems.

Therefore, the $A E T$ is an index derived from the calculation of the soil water balance, which represents the water lost in the form of vapor through evaporation from the soil and plant cover and transpiration by plants (Thornthwaite \& Mather, 1955). Therefore, its calculation requires combining each month's temperature and solar radiation data to calculate PTEs with Turc's formula and precipitation and maximum soil water reserve (MWR) values to estimate the available water stock (Piedallu et al., 2013).

Three methods are used to characterize the $A E T$ of this watershed:

Turc method (Turc, 1961): Turc's method allows us to evaluate the average annual runoff of rivers as a function of precipitation $(P$ in $\mathrm{mm})$ and temperature $\left(t\right.$ in $\left.{ }^{\circ} \mathrm{C}\right)$ using the following equation:

$$
A E T=\frac{P}{\sqrt{0.9+\frac{P^{2}}{L^{2}}}} \text { with } L=300+25 t+0.05 t^{3}
$$


where: Actual evapotranspiration $A E T(\mathrm{~mm}) ; P$. Average annual precipitation height $(\mathrm{mm})$; and $t$. Average annual temperature $\left({ }^{\circ} \mathrm{C}\right)$.

Coutagne method (Coutagne, 1954), who suggest that the effective deficit of flow $(A E T)$ should be symbolically expressed as a function of precipitation $(P)$ by a parabolic formula:

$$
A E T=P-\gamma P^{2} \quad \text { with } \quad \gamma=\frac{1}{0.8+0.14 \times T}
$$

where: $P$ : is the average annual precipitation $(\mathrm{m})$; and $T:$ is the annual average temperature $\left({ }^{\circ} \mathrm{C}\right)$.

Thornthwaite balance method (Thornthwaite \& Mather, 1955): The calculation of $A E T$ by this method depends on the Easily Usable Reserve (EUR) of the Soil. The maximum value for a soil to be saturated varies according to the region's climate; for humid areas, Thornthwaite admitted that soil is saturated when it absorbs a water flow equivalent to $100 \mathrm{~mm}$ of precipitation. On the other hand, this value can be reduced to $50 \mathrm{~mm}$ in the case of arid and semi-arid areas because the soil is not constantly saturated. Thornthwaite (1948) drew a correlation between monthly average temperature with monthly potential evapotranspiration. The Thornthwaite method is based on the following equation (in Naoura, 2012):

$$
P E T=16 \times\left(\frac{10 \times T}{I}\right)^{\alpha}
$$

where: PET: Potential evapotranspiration; T: Average temperature of the month considered, expressed in ${ }^{\circ} \mathrm{C}$; $I$ : The sum of the monthly thermal indices $i$ : $I=\sum i=\sum_{i=0}\left(\frac{T}{5}\right)^{1.514}$

In this equation $\alpha$ is a coefficient expressed as a function of the sum of the monthly thermal indices:

When

$$
10^{\circ} \mathrm{C} \leq I \leq 80^{\circ} \mathrm{C}: \quad \alpha=\left(\frac{1.6 \times I}{100}\right)+0.5
$$

Else:

$$
\alpha=\left(675 \times 10^{-9} \times I^{3}\right)-\left(771 \times 10^{-7} \times I^{2}\right)-\left(1792 \times 10^{-5} \times I\right)+0.49239
$$

\section{Evaluation of the waterfall amount}

The amount assessment of the water falling on the Sefrou watershed is estimated by several methods (The arithmetic mean, Theissen polygon method, and Isohyet method) allowing the integration of the point data relative to the different stations, and help to estimate the spatial precipitations.

Arithmetic mean: The annual arithmetic mean can be estimated by the following equation:

$$
P_{\text {avg }}=\frac{\sum_{i=1}^{n} P_{i}}{n}
$$


where $P_{\text {avg: }}$ Average precipitation over the watershed; $P_{i}$ : Precipitation height at station I; and $n$ : Number of stations in the watershed.

\section{Theissen polygon method}

Theissen polygon is a statistical method that averages the precipitation measured at the rainfall stations in the watershed region (Thiessen, 1911). The area of influence of each measuring station called Thiessen polygon is the weighting factor. These polygons are obtained graphically by plotting the perpendicular bisectors of the segments connecting two neighboring rain gauge stations on a geographical or topographical map.

The Thiessen polygon method is widely used because it is easy to apply and generally gives good results. It is particularly suitable when the rainfall network is not spatially homogeneous (irregularly distributed rain gauges). We perform the calculation using the following equation:

$$
P_{\text {avg }}=\frac{\sum_{i=1}^{n} A_{i} \times P_{i}}{A_{t}}
$$

where $P_{\text {avg: }}$ average precipitation over the watershed $(\mathrm{mm}) ; A_{i}$ total area of the watershed $\left(\mathrm{km}^{2}\right) ; P_{i}$ : precipitation recorded at station I; and $A_{i}$ : area of the polygon associated with the station $\left(\mathrm{km}^{2}\right)$.

\section{Isohyet method}

"The isohyetal method is used to estimate the mean precipitation across an area by drawing lines of equal precipitation. The method uses topographic and other data to yield reliable estimates" (Jain \& Singh, 2005). When drawing the isohyet curves, we calculate the average rainfall as follows:

$$
P_{a v g}=\frac{\sum_{i=1}^{k} A_{i} \times P_{i}}{A_{t}} \text { with } P_{i}=\frac{h_{i}+h_{i+1}}{2}
$$

where $P_{\text {avg: }}$ average precipitation over the basin $(\mathrm{mm}) ; A_{i}$ : total area of the watershed $\left(\mathrm{km}^{2}\right) ; A_{i}$ : surface between two isohyets $i$ and $i+1\left(\mathrm{~km}^{2}\right) ; k$. total number of isohyets; and $P_{i}$ average of the heights $\mathrm{h}$ of precipitation between two isohyets $i$ and $i+1(\mathrm{~mm})$.

\subsubsection{Hydrological Network}

We study the hydrological network (drainage density, torrentiality coefficient, hierarchy of the watershed, longitudinal profile) and its characterization. It consists of collecting data and analyzing monthly and annual rate flows and rain flow relationships. It allows determining the flow regime in the watershed and frequency analysis to choose the return period of floods and the adjustment of flows by statistical laws (Average of monthly and annual flows). In this study, we use the following methods and equations:

Drainage density, first defined by Horton (1945), is defined as the total length of channel in a drainage basin divided by the watershed total area, according to the following equation:

$$
D_{d}=\frac{\sum L}{A}
$$


where: $L$ : total length of the river system $(\mathrm{km})$; and $A$ : surface of the watershed $\left(\mathrm{km}^{2}\right)$

The torrentiality coefficient (or drainage texture) considers the frequency of elementary thalwegs (of low order, generally of order (1) by the drainage density. The torrentiality coefficient (for order 1 streams) estimates the adaptability of a watershed to surface runoff or infiltration.

It can be expressed by the Smith equation (Smith, 1950):

$$
T=D_{d} \times F_{s}
$$

where: $D_{d}$. drainage density, $\left(D_{d}=0.736 \mathrm{~km}^{-1}\right) ; F_{s}$ : designates the frequency of elementary thalwegs $\left(F_{s}=N_{1} / A\right.$; with $N_{1}$ : number of streams of order $1 ; F_{s}=$ $0.21)$.

To calculate the average annual flows, only the data of Ain Elouali station are available. The location of this station is in the North of the Sefrou watershed (Figure 8), with the following geographical coordinates: $X=555,650 \mathrm{~m} ; Y=$ $377,000 \mathrm{~m} ; Z=245 \mathrm{~m}$, downstream of the watershed towards the outlet. The Sebou Hydraulic Basin Agency kindly provided the monthly hydrological flows data. They cover the periods of 29 years: 1968 to 1970 and 1979 to 2005 . The data gap for the period 1970 to 1979 was filled by estimation, following the shape of the flow curve by statistical correlation methods. The specific flow $\left(Q_{s p}\right)$ measures of the annual average pluvial flow in a watershed is defined as the number of liters of water flowing on average each second per square kilometer of the basin. We use specific flow to express peak flows during floods, and in general, this peak decreases with increasing watershed size. For its calculation, we use the value of the flow $Q\left(1 / \mathrm{s}\right.$ or $\left.\mathrm{m}^{3} / \mathrm{s}\right)$ for the surface of the watershed ( $A$ in $\mathrm{km}^{2}$ ), and the equation corresponds to:

$$
Q_{s p}=\frac{Q}{A}
$$

In this methodology part, we emphasize the geographical and geological aspects, the occupation of soils (land use) as well as the characterization of the studied climatic zone according to the empirical climagram of Emberger (Sauvage, 1963).

\subsubsection{Emberger's Climagram}

We use the rainfall quotient (Emberger climate index, discussed in Calvet, 1979) to define the five different types of Mediterranean climates, from arid (desert) to humid (high mountain). Morocco is the only country in the Mediterranean region that has all five types. The Emberger rainfall quotient $(Q 2)$ is a synthetic expression of the Mediterranean climate, considering the annual average of rainfall and temperature (Sauvage, 1960). The latter take into consideration, on the one hand, the average of the minima of the coldest month $(\mathrm{m})$ and, on the other hand, the average of the maxima of the warmest month $(M)$. We use these two extreme thermal values to evaluate the average temperature $(M+m) / 2$ and the average mean thermal amplitude $(M-m)$. We calculate this quotient ac- 
cording to the following equation:

$$
Q 2=\frac{2000 \times P}{(M+m)(M-m)}
$$

where $Q$ : Emberger's rainfall quotient; $P$. average annual precipitation $(P=$ $454.22 \mathrm{~mm}$ ); $M$ : average of maximum of hottest month ( $M=307.79^{\circ}$ Kelvin; $M$ $\left.=34.64{ }^{\circ} \mathrm{C}\right)$; $m$ : average of the minima of the coldest month $\left(m=276.71^{\circ}\right.$ Kelvin; $\left.m=3.56{ }^{\circ} \mathrm{C}\right)$.

$$
Q 2=50.1
$$

Emberger bases his method on the surface limits of the various plant species, with $Q 2$ values on the ordinate and minima average of the coldest month $\left({ }^{\circ} \mathrm{C}\right)$ on the abscissa of his climatogram. The graphical representation of the Sefrou watershed is as follows (Figure 4). The projection allows us to locate the catchment area of Sefrou in the semi-arid climatic zone with temperate winter.

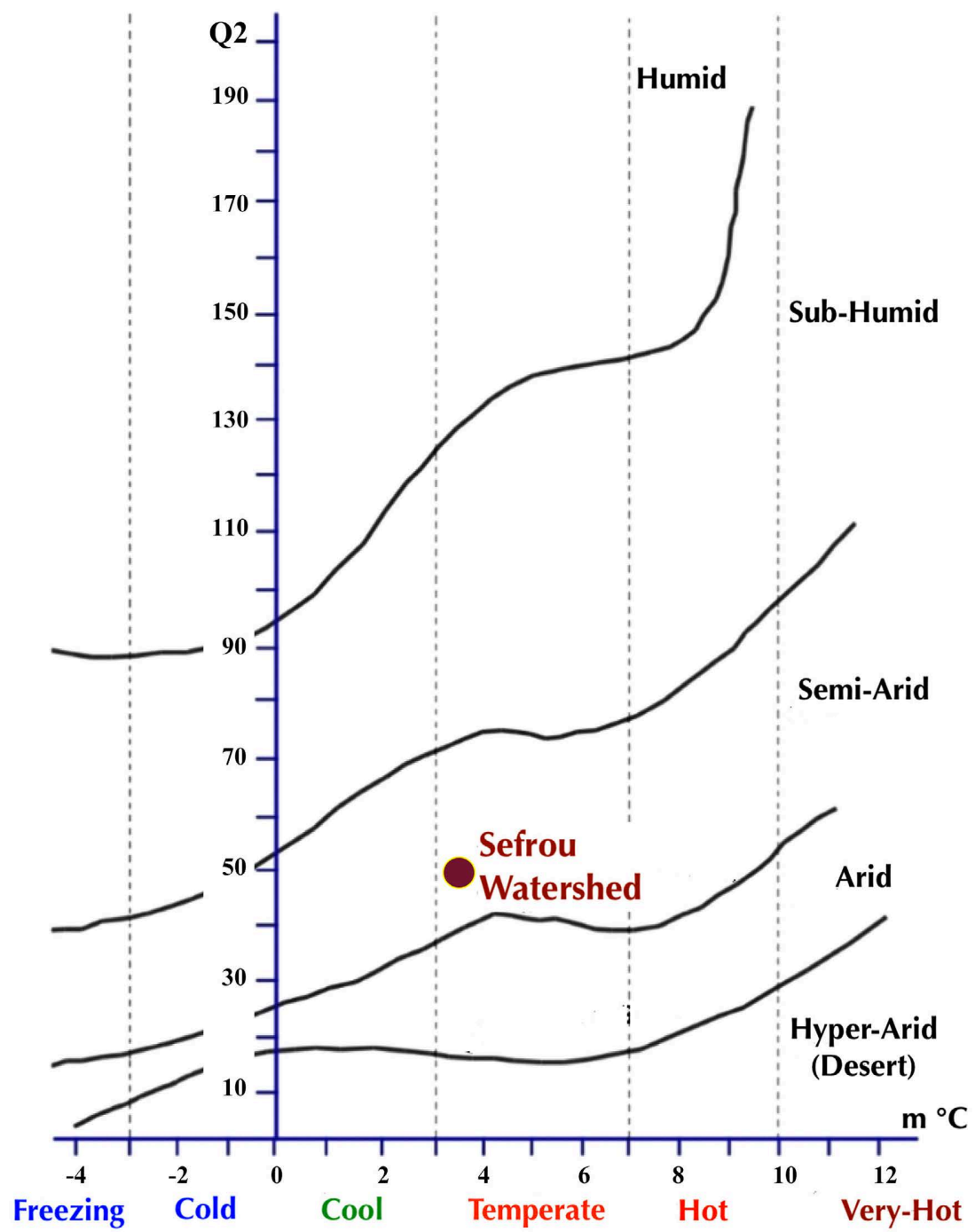

Figure 4. Emberger Climagram of the Sefrou watershed. The bioclimatic zonation's are adapted to the definition of Sauvage (1963). 


\section{Results and Discussion}

\subsection{Physical Characteristics of the Watershed}

\subsubsection{Relief Characteristics}

The Sefrou watershed relief characteristics study allows us to determine its morphology, interactions with meteorological phenomena, and hydrological behavior. The relief directly influences all the hydroclimatic indicators (i.e. precipitation, temperature, vegetation, runoff).

\section{Hypsometric curve}

To better understand the variations in altitude within the Sefrou watershed, we determined a hypsometric curve that allowed us to translate the distribution of altitudes within the study area. This curve also allows us to determine the characteristic altitudes (Figure 5).

From this curve, we conclude that the altitude varies enormously despite the relatively small surface area of the studied watershed, thus corresponding to a steep watershed.

Using the Equation (1) and the observation data (Figure 5) yields an average altitude of: $H_{\text {avg }}=928.36 \mathrm{~m}$.

The median altitude is the value found at $50 \%$ of the total watershed area (Equations (2) and (3)).

On the hypsometric curve, the median altitude is $H_{\text {Med }}=905 \mathrm{~m}$.

\section{Concentration time}

We calculate the Concentration time according to Equation (4) from the following data: $A$ : area of the watershed $\left(\mathrm{km}^{2}\right)=405 \mathrm{~km}^{2} ; L$ : length of the main thalweg watercourse $=45.68 \mathrm{~km} ; H_{\text {avg: }}$ average altitude $(\mathrm{m})=928.36 \mathrm{~m}$.

The Sefrou watershed Concentration-time is: $T_{c}=6 \mathrm{~h} 11 \mathrm{~min}$. This result classifies the Sefrou watershed as having a relatively short time of concentration.

The global slope index

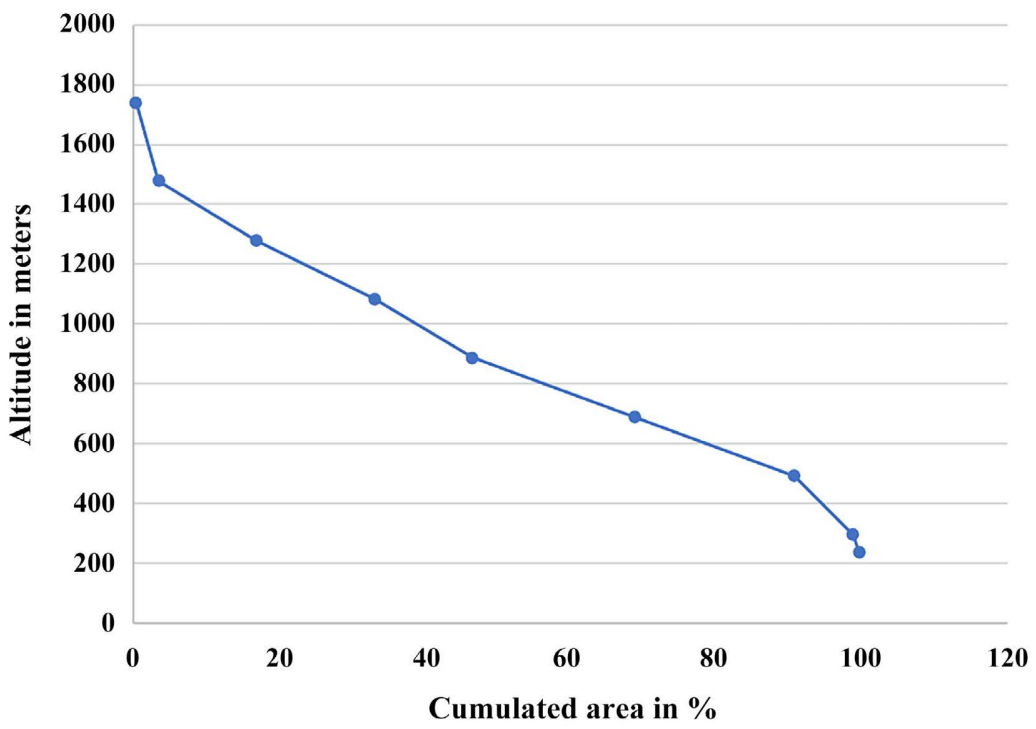

Figure 5. Hypsometric curve of the Sefrou watershed. 
We determine $H_{5 \%}$ and $H_{95 \%}$ using the hypsometric curve, thus $D_{u}=1080 \mathrm{~m}$. In addition to that, from our initial parameters we know that: $L_{e q}=56.43 \mathrm{~km}$. Therefore, the global slope index, according to Equation (5), will be:

$$
\begin{gathered}
I_{g}=\frac{1080}{56.43}=19.13 \mathrm{~m} / \mathrm{km} \\
I_{g} \approx 0.019 \%
\end{gathered}
$$

The overall index of slope given by the formula is $19.13 \%$ or $0.019 \%$. According to the classification of the relief given by the ORSTOM (Msatef et al., 2018), the value of the global index of slope of the Sefrou watershed shows that the relief is quite important (moderate relief).

\subsubsection{Physiographic Characteristics of the Sefrou Watershed}

The digitization of the Sefrou watershed covers $404.89 \mathrm{~km}^{2}$, with a perimeter of $127.42 \mathrm{~km}$. It shows that the shape of the hydrograph at the exit of the watershed depends on the latter's form. This characterization is due to the different morphological indices that enable understanding and comparison with other watersheds. These indices are:

\section{Gravilius's compactness index $\left(K_{c}\right)$}

We use the Equation (6) to calculate $K_{c}$ in the Sefrou watershed.

$K_{c}=1.786$; this value allows us to conclude that the watershed is elongated with a potential linear erosion. For the same rainfall, this shape favors low flood peak flows because of the delay in water routing to the outlet.

\section{Horton's compactness index}

In Sefrou's watershed we found the that (Equation (7)): $W_{\text {avg }}=13.56 \mathrm{~km}$ et $L$ $=45.76 \mathrm{~km}$. Therefore, Horton's compactness index is:

$$
K_{h}=\frac{13.56}{45.76^{2}}=0.0647 \mathrm{~km}^{-1}
$$

As the value of $K_{h}$ is very low, this confirms that the Sefrou watershed is elongated.

In summary of the different physiographic characteristics, the Sefrou watershed (Table 2) shows parameters characterizing the relief of an elongated watershed. The hypsometric curve shows a relief that decreases towards the exit of the basin (northern part of the study area). The relatively middle altitudes ( 500 to $900 \mathrm{~m}$ ) are the most frequent.

The hydrographic network is relatively denser on the right bank than on the left one of the main river, and the two banks remain almost symmetrical according to their surfaces.

\subsection{Climate Context of the Watershed}

\subsubsection{Rainfall Conditions}

The Rainfall conditions of the watershed when examining the monthly rainfall averages shows that December is the wettest month of all stations, with a maximum recorded of $54.92 \mathrm{~mm}$. Conversely, July is the driest month, with an average rainfall of $3.86 \mathrm{~mm}$ (Figure 6). 


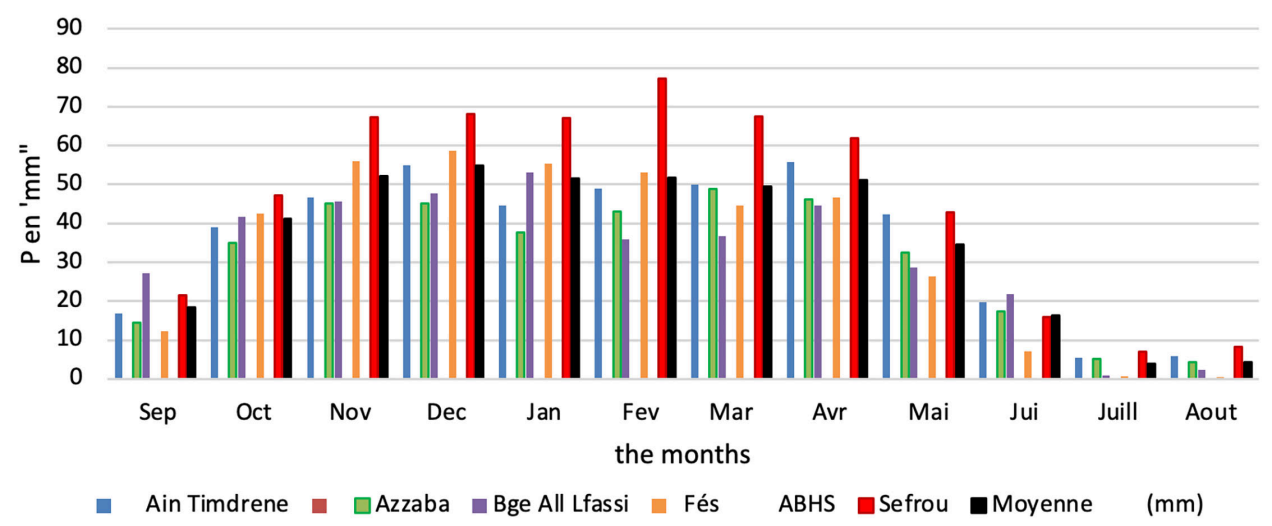

Figure 6. Monthly average precipitation in different stations of the Sefrou watershed.

Table 2. Physiography characteristics of the Sefrou watershed.

\begin{tabular}{|c|c|c|}
\hline \multirow{6}{*}{ Shape characteristics } & Perimeter $(\mathrm{km})$ & 127.42 \\
\hline & Perimeter $(\mathrm{km})$ & 404.89 \\
\hline & Gravelius Compactness Index $\left(K_{c}\right)$ & 1.786 \\
\hline & Horton compactness index $\left(K_{h}\right)$ & 0.0647 \\
\hline & Length of equivalent rectangle $(\mathrm{km})$ & 57.089 \\
\hline & Width of equivalent rectangle $(\mathrm{km})$ & 7.094 \\
\hline \multirow{6}{*}{$\begin{array}{l}\text { Characteristics of the } \\
\text { relief }\end{array}$} & Maximum altitude $(\mathrm{m})$ & 1766 \\
\hline & Minimum altitude $(\mathrm{m})$ & 241 \\
\hline & Average altitude (m) & 928.36 \\
\hline & Median altitude (m) & 905 \\
\hline & global slope index (\%) & 0.019 \\
\hline & Concentration time $\left(T_{c}\right)$ & $6 \mathrm{~h} 11 \mathrm{~min}$ \\
\hline \multirow{2}{*}{$\begin{array}{l}\text { Hydrological } \\
\text { characteristics }\end{array}$} & Length of the hydrographic network $(\mathrm{km})$ & 298.207 \\
\hline & Drainage density $(\mathrm{km})$ & 0.736 \\
\hline
\end{tabular}

Annual precipitation decreases towards the SE of this watershed and directly influences runoff flow as follows: Sefrou: $517.2 \mathrm{~mm} / \mathrm{y}$; Anoceur station: 504 mm/y; Ain Timedrine: 407.4 mm/y; Allal Elfassi Dam: 335.3 mm/y; Azaba: 361 $\mathrm{mm} / \mathrm{y}$; and Fez: $396.2 \mathrm{~mm} / \mathrm{y}$.

The average precipitation for the study area is $420 \mathrm{~mm} /$ year, calculated from the results obtained in the six stations between 1957 and 2010. The orographic effect explains these variations due to the presence of sequences of high peaks in this region.

\subsubsection{Potential Evapotranspiration, Actual Evapotranspiration and Runoff Deficit}

\section{Potential evapotranspiration}

The monthly PET values calculated for the watershed show significant fluctuations during the year. A minimum of $21.765 \mathrm{~mm}$ in January and a maximum of $130.65 \mathrm{~mm}$ in July and August explains this fluctuation. On the one hand, the 
low values recorded during the cold period are due to the low temperatures and the relatively high air humidity during the winter months. On the other hand, the high values of $P E T$ found in the hot period reflect conditions opposite to the cold period, i.e., high temperatures, low humidity, and low rainfall.

Furthermore, a third factor influencing the PET value is the low rate of transpiration caused by plants (in the Sefrou watershed, there is a relatively average rate of vegetation density).

\section{Actual evapotranspiration}

In Sefrou's watershed, the actual evapotranspiration ( $A E T)$ is very important because it explains the water and energy exchanges between the soil, the land surface, and the atmosphere. We have calculated it for the Sefrou watershed using the average of the three methods (Thornthwaite, 1948; Thornthwaite \& Mather, 1955; Coutagne, 1954; Turc, 1955).

Turc method (Turc, 1961)

The value of the $A E T$, calculated by the Turc method for the entire watershed is: $\mathrm{L} 967.63^{\circ} \mathrm{C}$; Therefore the actual evapotranspiration is (from Equation (8)):

$$
A E T=\frac{454.22}{\sqrt{\left(0.9+\frac{454.22^{2}}{967.63^{2}}\right)}}=429.13 \mathrm{~mm} / \text { year }
$$

Coutagne method (Coutagne, 1954)

The value of the $A E T$ calculated by the Coutagne method is (from Equation (9)):

$$
\begin{aligned}
& \gamma=0.29 . \\
& P=0.45422 \mathrm{~m} . \\
& A E T=0.39548 \mathrm{~m} / \text { year }=395.48 \mathrm{~mm} / \text { year. }
\end{aligned}
$$

Thornthwaite balance method (Thornthwaite et al., 1955)

To establish a balance that is undoubtedly correct, we use Equation (10), and we consider the two distinct periods:

- We have more precipitation during the Humid period, so when: $P+E U R \geq P E T \rightarrow A E T=P E T$, we have a water excess $(P-A E T)$, which will fill the EUR; the rest will feed the surface runoff and/or deep infiltration.

- During the Dry period, we have: $P+E U R \leq P E T \rightarrow A E T=P+E U R$, and two cases arise:

- First, $E U R$ is sufficient, then: $A E T=P E T$; in that case, $P E T$ is satisfied, and the $E U R=E U R$-complement to PET.

- Second, EUR is insufficient or null, then: $P \leq A E T \leq P E T$, this leads to the appearance of a deficit.

Analysis of the Table 4 representing the Thornthwaite balance results for the Sefrou watershed is as follow:

- The monthly $A E T$ is maximum in the fall and spring months based on favorable weather conditions,

- The deficit reaches its maximum during the summer months due to the high PET values. 
- The excess represents its maximum values for the winter months, which favors the watercourses feeding and the infiltration of the underground flows.

- The annual average $A E T$ value deduced from the Thornthwaite balance is $345.995 \mathrm{~mm} /$ year.

By using Equations (10, 11 and 12), In the case the Sefrou watershed, we found that $I=\sum_{i=1}^{12} i=79.50^{\circ} \mathrm{C}$.

Since $I$ is the range $[10,80]$, we will compute the coefficient $\alpha$ used the first formula:

$$
\alpha=\left(\frac{1.6 \times I}{100}\right)+0.5=1.772
$$

The calculation of the $A E T$ by the Thornthwaite method is the following (Table 3).

\section{Average AET calculation}

The average $A E T$ calculation using the three methods is (Table 4).

The average amount of water lost over a year through evapotranspiration is $390.20 \mathrm{~mm}$.

\subsubsection{Assessment of the Amount of Water Falling on the Sefrou Watershed}

Arithmetic mean: $P_{1}, P_{2}, P_{3}, P_{4}, P_{5}$, and $P_{6}$ are the annual average rainfall of the stations of Ain Timedrine, Sefrou, Azaba, Fez ABHS, Anoceur, and Allal Elfassi Dam, respectively over the whole series (1957-2010).

From paragraph (3.2.1.) we know that:

Table 3. Calculation of the AET by the Thornthwaite method.

\begin{tabular}{cccccccc}
\hline & $P(\mathrm{~mm})$ & $P E T(\mathrm{~mm})$ & $P-P E T$ & $E U R$ & $A E T(\mathrm{~mm})$ & Excess & Deficit \\
\hline Sep & 18.42 & 104.1 & -85.7 & 0 & 18.42 & - & 85.68 \\
Oct & 41.1 & 56.215 & -15.15 & 0 & 41.1 & - & 15.12 \\
Nov & 52.1 & 43.891 & 8.21 & 9.21 & 43.891 & - & - \\
Dec & 54.92 & 27.788 & 27.14 & 27.13 & 27.788 & - & - \\
Jan & 51.56 & 21.765 & 29.8 & 50 & 21.765 & 6.93 & - \\
Feb & 51.68 & 27.833 & 23.84 & 50 & 27.833 & 23.84 & - \\
Mar & 49.56 & 39.304 & 10.26 & 50 & 39.304 & 10.26 & - \\
Apr & 51.04 & 46.634 & 4.41 & 50 & 46.634 & 4.41 & - \\
May & 34.5 & 63.225 & -29.72 & 20.28 & 34.5 & - & - \\
June & 16.36 & 98.04 & -81.68 & 0 & 36.64 & - & 61.4 \\
July & 3.86 & 130.65 & -126.79 & 0 & 3.86 & - & 126.79 \\
Aug & 4.26 & 129.68 & -125.42 & 0 & 4.26 & - & 125.42 \\
Total & 429.36 & $\mathbf{7 8 9 . 1 2}$ & -360.8 & 256.62 & 345.99 & 45.44 & 414.41 \\
\hline
\end{tabular}

Table 4. Average AET calculation.

\begin{tabular}{ccccc}
\hline & Turc & Coutagne & Thornthwaite & Average \\
\hline$E T R(\mathrm{~mm})$ & 429.13 & 395.48 & 345.995 & $\mathbf{3 9 0 . 2 0}$ \\
\hline
\end{tabular}


- $P_{\text {Sefrou }}=517.2 \mathrm{~mm} / \mathrm{y}$,

- $P_{\text {Anoceur station }}=504 \mathrm{~mm} / \mathrm{y}$,

- $P_{\text {Ain Timedrine }}=407.4 \mathrm{~mm} / \mathrm{y}$,

- $P_{\text {Allal ElFassi Dam }}=335.3 \mathrm{~mm} / \mathrm{y}$,

- $P_{\text {Azzaba }}=361 \mathrm{~mm} / \mathrm{y}$,

- $P_{\text {Fеz }}=396.2 \mathrm{~mm} / \mathrm{y}$.

Accordingly to Equation (13) where $n=6$, the annual arithmetic mean can be estimated as follow:

$$
P_{a v g}:=\frac{\sum_{i=1}^{n} P_{i}}{6}=420.18 \mathrm{~mm}
$$

\section{Theissen polygon method}

We use the statistical Theissen polygon method (Equation (14)) to quantify the averages of the precipitation measured at the rainfall stations in the watershed region (Table 5 and Figure 7).

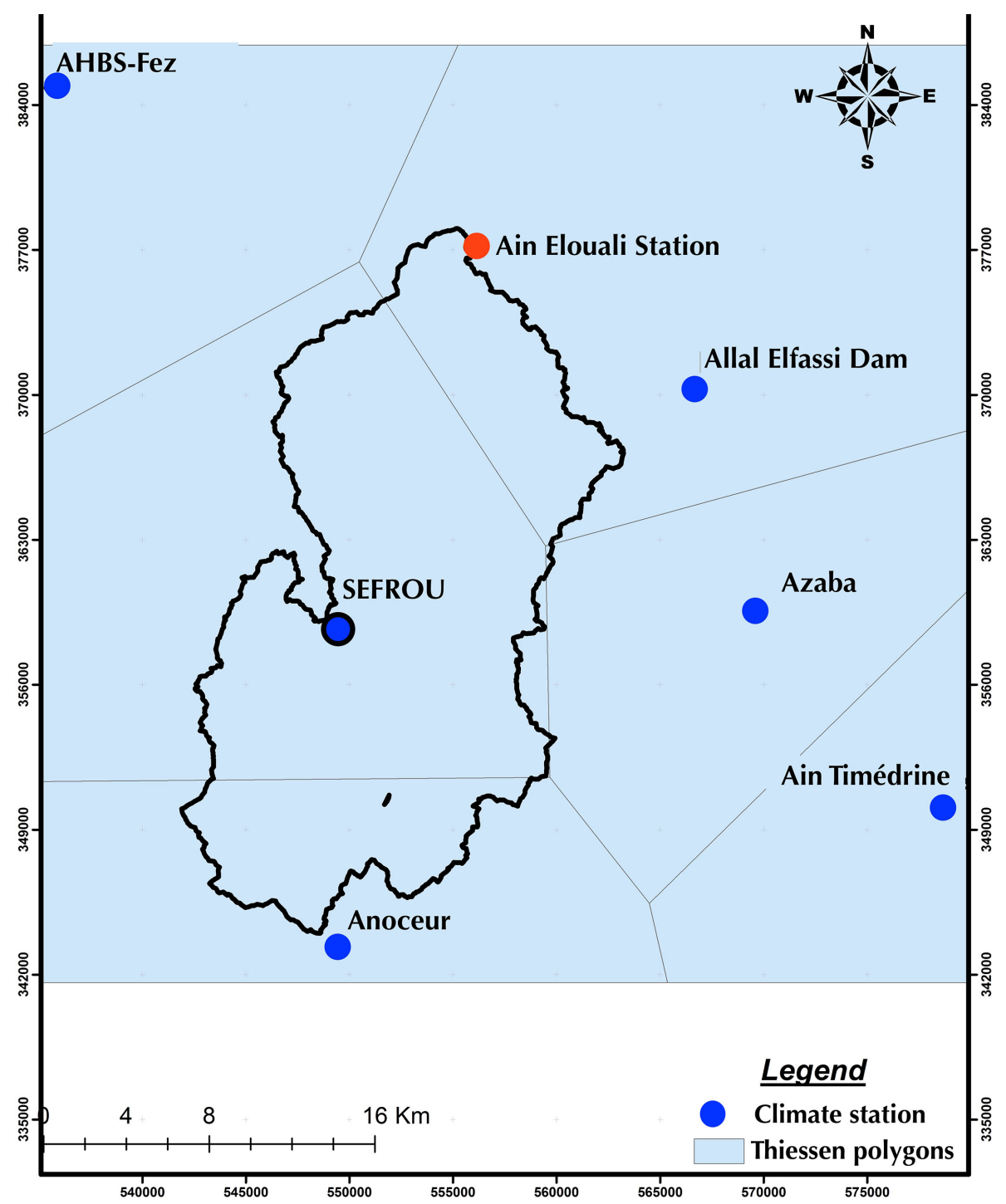

Figure 7. Map of the Thiessen polygons of the Sefrou watershed. 
Table 5. Surface of polygons and average precipitation by Theissen method.

\begin{tabular}{cccc}
\hline Station & $A_{i}$ Area $\left(\mathrm{km}^{2}\right)$ & $P_{i}$ & $P_{i} \times A_{i}$ \\
\hline Sefrou & 257.54 & 517.2 & $133,199.68$ \\
Allal Elfassi Dam & 72.78 & 335.3 & $24,401.79$ \\
Azzaba & 0.38 & 361 & 137.68 \\
Anoceur & 74.19 & 504 & $37,392.77$ \\
Total $\left(A_{t}\right)$ & 404.89 & & \\
\hline
\end{tabular}

The amount of water falling on the Sefrou watershed $P_{\text {avg }}=481.93 \mathrm{~mm}$.

\section{Isohyet method}

The isohyet map shows a progressive precipitation gradient between the different stations, thus facilitating the interpretation of precipitation. The precipitation gradient increases from north to south towards the higher altitudes (Table 6 and Figure 8). Therefore, precipitations are high at the stations located at higher altitudes. Moreover, we see that certain summer months are characterized by the predominance of rainfall, mainly due to the frequency of local thunderstorms. These are due to the high insolation on the ground, which sometimes gives rise to updrafts that cause stormy precipitation.

The fallen water depth calculated by this method is $P_{\text {arg }}=460.87 \mathrm{~mm}$.

\section{Estimated mean of the water slide calculated by the three methods}

We use the average value between the three methods to quantify the volume of water falling on the Sefrou watershed (Table 7).

The annual rainfall volume (in $\mathrm{m}^{3}$ ), for the Sefrou watershed, is estimated as follows:

$$
V=P_{\text {avg }} \times S
$$

where $V$ : volume of the falling water in the watershed $\left(\mathrm{m}^{3} / \mathrm{year}\right) ; P_{\text {avg: }}$ average rainfall of the three methods (i.e.: $454.22 \mathrm{~mm} /$ year); and $S$ : total surface of the watershed (i.e.: $404.89 \mathrm{~km}^{2}$ ).

$$
V=454.22 \times 404.89=183.909 \times 10^{6} \mathrm{~m}^{3} / \text { year }
$$

In Summary, the result obtained for the $A E T$ is $390.20 \mathrm{~mm} /$ year for the entire Sefrou watershed, while the annual average rainfall represents a value of 454.22 $\mathrm{mm}$. Out of total annual precipitation of 183.909 million $\mathrm{m}^{3} / \mathrm{year}$ for this watershed, the generated loss by this process is about $85.90 \%$ of the inflow to the water system, with a volume close to 157.988 million $\mathrm{m}^{3} /$ year. In comparison, the difference represents the volume of water drained and the amount of underground infiltration, which reaches $14.09 \%$ (or 25.921 million $\mathrm{m}^{3} /$ year), according to the following calculation:

The water retained volume by the soil is:

$$
V_{\text {Ret }}=(454.22-390.20) \times 404.89=25.921 \times 10^{6} \mathrm{~m}^{3} / \text { year }:(14.09 \%) \text {, }
$$




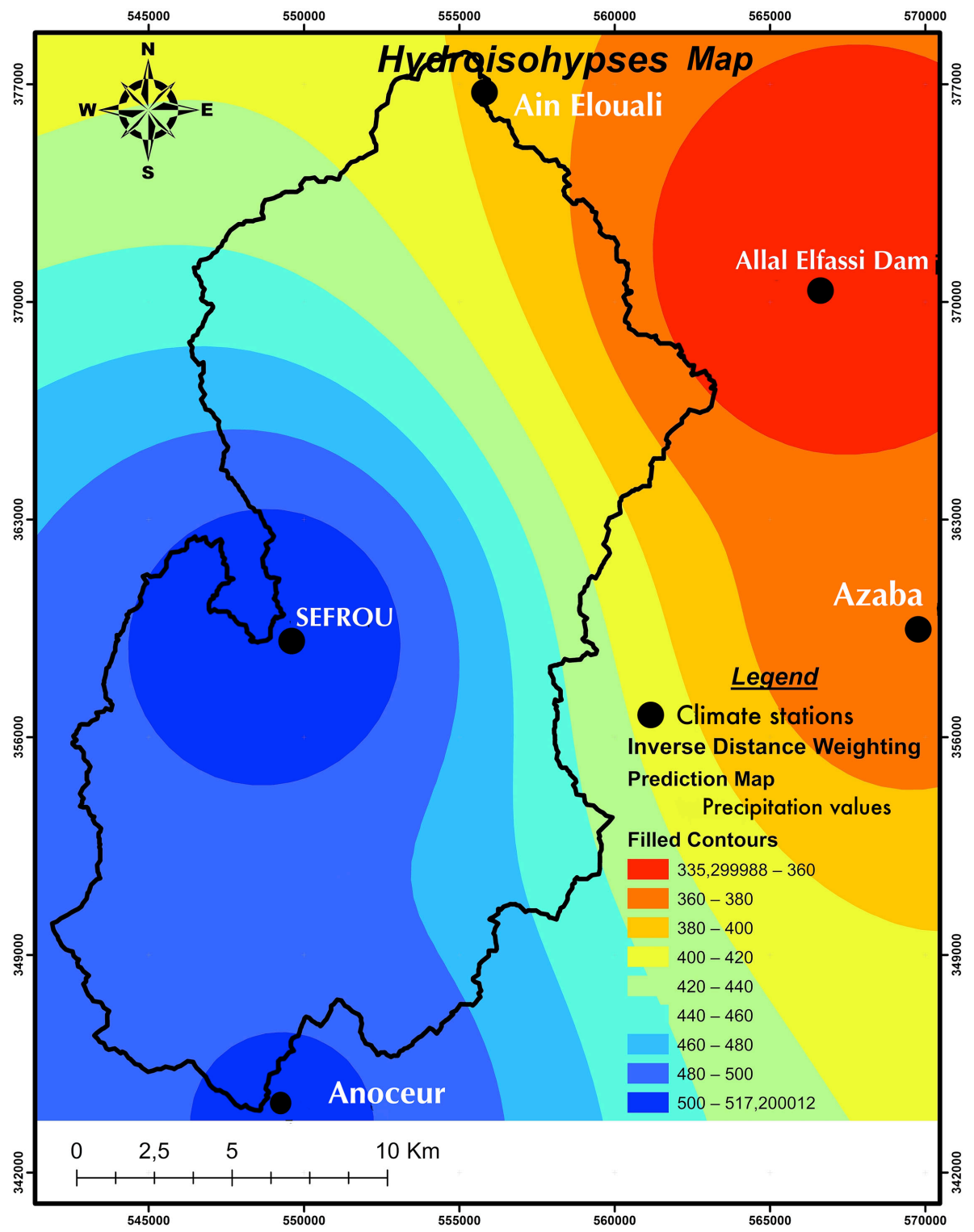

Figure 8. Hydroisohypses map of the Sefrou watershed by ArcGis.

Table 6. Calculation of the water slide fallen by the isohyet's method.

\begin{tabular}{cccc}
\hline Isohyet & $P_{i}(\mathrm{~mm})$ & $A_{i}\left(\mathrm{~km}^{2}\right)$ & $P_{i} \cdot A_{i}$ \\
\hline$P<360$ & 347 & 0.47 & 163.09 \\
$360<P<380$ & 370 & 16.23 & 6005.1 \\
$380<P<400$ & 390 & 35.49 & $13,841.1$ \\
$400<P<420$ & 410 & 35.33 & $14,485.3$ \\
$420<P<440$ & 430 & 36.79 & $15,819.7$ \\
$440<P<460$ & 450 & 41.69 & $18,760.5$ \\
$460<P<480$ & 470 & 39.29 & $18,466.3$ \\
$480<P<500$ & 490 & 133.37 & $65,351.3$ \\
$P>500$ & 509 & 66.21 & $33,700.89$ \\
Total & & 404.86 & $186,593.28$ \\
$P_{\text {avg }}(\mathrm{mm})$ & & & 460.87 \\
\hline
\end{tabular}


Table 7. Average rainfall by the three methods.

\begin{tabular}{ccccc}
\hline Methods & Arithmetic average & Thiessen polygons & Isohyets & Average \\
\hline$P_{\text {average }}(\mathrm{mm})$ & 420.18 & 481.93 & 460.87 & 454.22 \\
\hline
\end{tabular}

And the evaporated water volume is:

$$
V_{\text {evap }}=390.20 \times 404.89=157.988 \times 10^{6} \mathrm{~m}^{3} / \text { year }:(85.90 \%) \text {. }
$$

\subsection{The Hydrographical Network}

The hydrographical network refers to hierarchical and structured channels ensuring a watershed or region's permanent or temporary drainage surface. This hierarchy is characterized by the increasing number of constituents from the first upstream ramification (order 1 of Strahler's classification, Strahler, 1952) to the primary collector. This ranking increases with the watershed size, the number of tributaries, and drainage density (order 2, 3, 4, 5, or more). The density of a river's tributaries increases under the following conditions: wet climate, steep slopes, and less porous rocks or surface formations.

Using the ArcHydro function of ArcGis, we were able to calculate the length of the main river and thalwegs of the Sefrou watershed. Thus, from upstream and high altitudes to the outlet, the main river extends over $45.68 \mathrm{~km}$. The direction of flow of this watershed is from south to north.

\subsubsection{Drainage Density}

We calculate the Sefrou watershed drainage density from Equation (16):

$$
D_{d}=0.736 \mathrm{~km}^{-1}
$$

The obtained value of $D_{d}$ implies that the hydrographic network of the Sefrou watershed is dense.

\subsubsection{Torrentiality Coefficient}

The Sefrou watershed Torrentiality coefficient is (Equation (17)): $T=0.154$.

According to Smith table (Smith, 1950), $T$ indicates that it is a coarse texture. The value of $T$ is relatively low since the torrentiality coefficient depends directly on the time of concentration $\left(T_{c}=6 \mathrm{~h} 11 \mathrm{~min}\right.$ ); this value is related to several natural indicators, such as climate, precipitation, vegetation cover, soil type, infiltration capacity, and terrain.

\subsubsection{Longitudinal Profile of the Watershed}

Using the profile along the main river (Figure 9), we can estimate the slope average and calculate the $T_{c}$ value (Concentration-Time). We note several breaks in slope indicating erosion at the break section, while the main tributaries occupy the right bank with appreciable density.

In Summary, to characterize the hydrographic network of the Sefrou watershed, we calculate the density of drainage, and the obtained value $\left(D_{d}\right)$ implies that it is dense. The low permeability of some geological components (red Triassic 


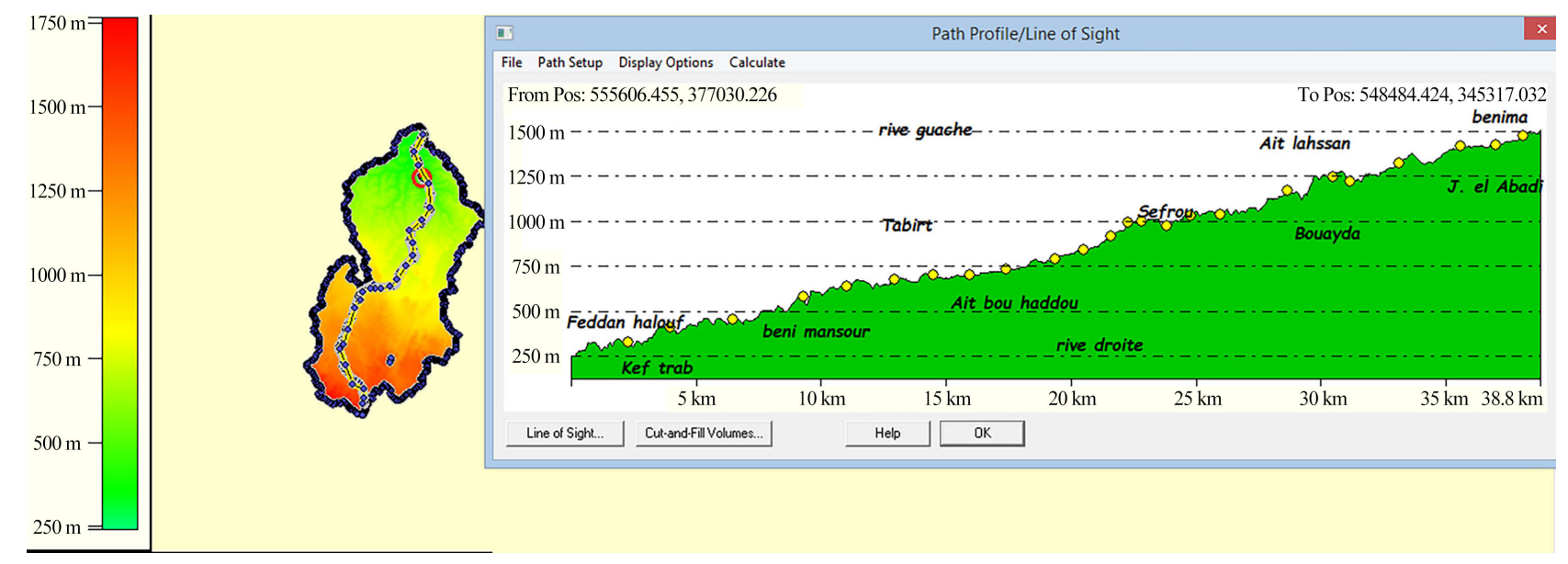

Figure 9. Longitudinal profile of the Sefrou watershed.

clays and Miocene marls in the northern part of the watershed), the vegetation cover's weakness, and the mountainous relief in its southern part favor the acceleration of runoff and floods. The watershed's morphology and the slope index's calculation have shown several slope breaks, with intense erosion. These slopes are frequent in the southern (highest) part of the watershed and directly influence water runoff. Added to this is the high intensity of the hydrographic network of the main river right bank of the watershed (Wadi Aggay), which increases the runoff. Knowing that the Concentration-Time $\left(T_{c}\right)$ influences the maximum flow observed, these slopes accelerate the surface flow.

The value obtained for the Torrentiality Coefficient $(T)$ attests that this watershed has a coarse texture. The latter has a relatively low value and directly depends on the Concentration-Time $\left(T_{c}\right)$. It's linked to several natural indicators, such as climate, precipitation, vegetation cover, soil type, infiltration capacity, and relief.

The elongated form of the watershed, relatively strong stream slopes and low permeability outcrops are all indicators that influence the flow of very muddy surface water and the decrease in the infiltration/runoff ratio. Thus, the physical environment and climate may provide a suitable environment for the sudden flooding of rivers caused by heavy rainfall. So surface water's response and Concentration-Time are shortened. This condition suggests carefully monitoring the protection of arable soils against flooding and erosion and installing barriers and a dam to recharge the area's groundwater and artificially store surface water. Ouzerbane et al. (2019) described identical features in the Essaouira watershed (SW Morocco).

\subsection{Hydrological Characterization}

\subsubsection{Average Annual Flow}

The curve obtained from the AHBS data (Figure 10) represents the evolution of the annual flow over the period under consideration; the annual average of this flow is $454.22 \mathrm{l} / \mathrm{s}$; Equation (18): 


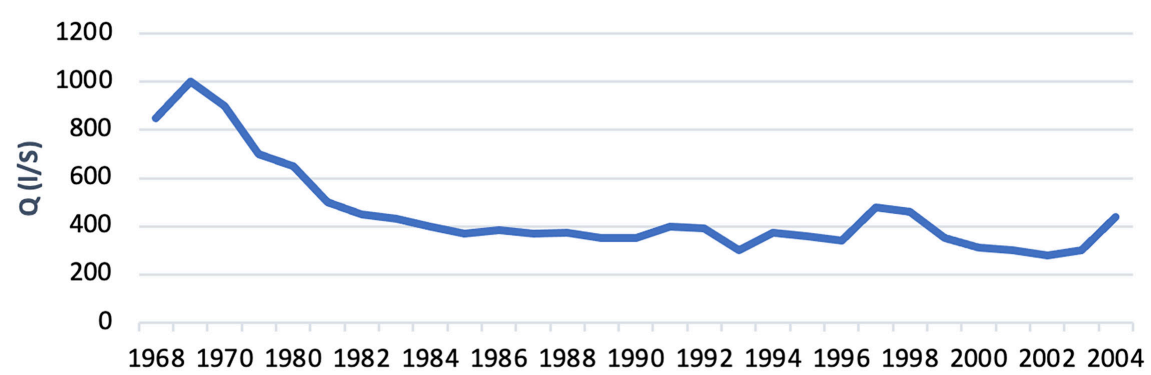

Figure 10. Annual flow variation of the Sefrou watershed.

$$
Q_{s p}=1.121\left(\mathrm{l} / \mathrm{s} / \mathrm{km}^{2}\right)
$$

For the Sefrou watershed, the highest interannual mean flow is $1000 \mathrm{l} / \mathrm{s} \mathrm{rec-}$ orded in 1969, while the lowest is $280 \mathrm{l} / \mathrm{s}$ recorded in 2002.

\subsubsection{Average Monthly Flow}

The maximum monthly average flow appears in March (390 1/s), while the minimum occurs in August ( $325 \mathrm{l} / \mathrm{s})$. The following hydrograph shows the variation of the monthly average flows at Ain Elouali station (Figure 11).

The graph lecture shows that water concentration requires seven months, i.e., from September to March, to reach its maximum (peak in March with 390 1/s). The time of flooding starts from the end of March until August (five months to reach the minimum quantity of this flow). The flood and receding times are approximate since we are working with an average monthly flow.

\subsubsection{Rainfall-Flow Relationship}

When comparing the hydrograph of average monthly flows $(Q)$ and monthly precipitation $(H)$ for the period 1968 to 2005 (Figure 11), we see that the flows and monthly precipitation are synchronous. Indeed, the two curves plotted for the same period evolve in about the same way. The decrease in rainfall inflows is accompanied by a late reduction of inflows, recorded around the summer months. These are maximum rainfall values in December and January, followed by maximum flow in March, with a one-month lag. This time lag is necessary to arrive at significant inflows at the measuring station near the watershed outlet. This delay can be explained by the lithological nature of the watershed or by its morphology. Runoff is one of the most significant components of a precipitation-fed hydrological regime.

In Summary, the Sefrou watershed water balance assessment (Table 8), where the maximum percentage is that of evapotranspiration $(87.67 \%)$. The high-temperature values can explain this during the dry period and the low evolution of vegetation in the studied area. The Sefrou watershed hydrology aspects correspond to the Mediterranean character, where the dry season is strongly pronounced. Therefore, it was evident that the hydrological drought has been well marked during the last forty years, confirmed by the differences in the interannual average flows. 


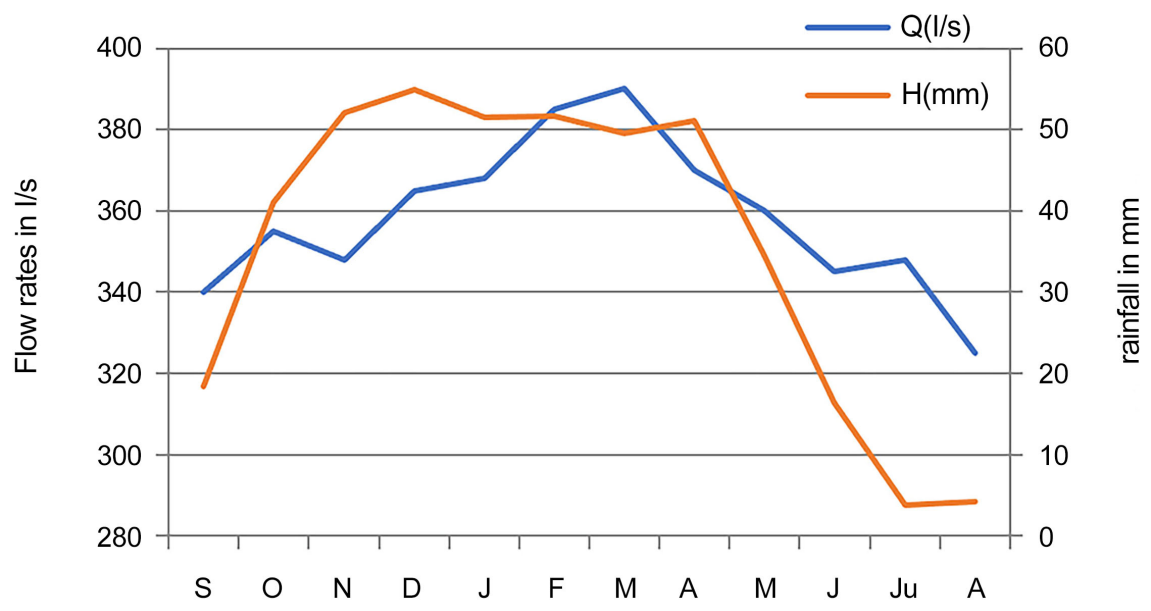

Figure 11. Hydrograph of precipitation and monthly variation in flow from Oued Sefrou to Ain Elouali station.

Table 8. Water balance of the watershed.

\begin{tabular}{ccccc}
\hline & Inputs & \multicolumn{3}{c}{ Outputs } \\
\cline { 2 - 5 } & Precipitation & Evapotranspiration & Runoff & Infiltration \\
\hline Volume $\mathrm{m}^{3} /$ year $\left(10^{6}\right)$ & 183.96 & 161.28 & 11.21 & 11.47 \\
Percentage & $100 \%$ & $87.67 \%$ & $6.09 \%$ & $6.23 \%$ \\
\hline
\end{tabular}

Fluctuations and hydrological cycles characterize the rainfall values collected at the stations from 1957 to 2011 . Moreover, the annual and monthly precipitation means are $454.22 \mathrm{~mm}$ and $35.45 \mathrm{~mm}$, respectively. Furthermore, the yearly average temperature is $16.62^{\circ} \mathrm{C}$. Using the different methods, the combination of temperature and precipitation showed that the Sefrou watershed is globally under a semi-arid climate. The average value of actual evapotranspiration (AET) is $389.22 \mathrm{~mm}$. Therefore, the study of the hydrological regime implies that an unstable regime characterizes the Sefrou watershed.

The analysis of the obtained data shows that the Rainfall-Flow Relationship is one of the essential components of the hydrological regime of the Sefrou watershed, fed mainly by rainfall. The lithological nature and morphology contribute to understanding its behavior related to precipitation.

The Sefrou watershed's highest average annual flow is $1000 \mathrm{l} / \mathrm{s}$ recorded in 1969 , while the lowest is $280 \mathrm{l} / \mathrm{s}$ recorded in 2002 . Concerning the monthly average flow, its maximum occurs in March (390 1/s), while the minimum occurs in August ( $325 \mathrm{l} / \mathrm{s})$. In the same way, the flooding starts from April until August (five months to reach the minimum quantity of this flow). Therefore, the flood and receding times are approximate since we work with a monthly average flow.

According to our results, the Sefrou watershed provides natural water resources. It ensures drinking water supply to the inhabitants of the northern Middle Atlas area and, more particularly, to the Sefrou habitats. Despite the 
usefulness of these essential capacities, they were causing risks represented by winter floods causing human and material damage. Therefore the creation of development projects in the region can solve the problem.

Finally, it seems that these characteristics are not specific to the Sefrou watershed, but somewhat identical in other watersheds, such as the adjacent watershed of Ouergha (Msatef et al., 2018), the Upper Sebou watershed (Qadem, 2015), and that of Wadi El Abid watershed in the High Atlas (Layati et al., 2021).

\section{Conclusion}

This study contributes to the physiographic and hydrological knowledge of the Sefrou watershed. It completes the global vision of the great Sebou basin in northern Morocco. This watershed shows that it is a semi-arid bioclimatic zone with temperate winter, abundant rainfall in winter, and very high flows. However, the summer period knows a drought which is sometimes strongly pronounced.

Rainfall measurements collected over the past 60 years show fluctuations between the different stations and hydrological cycles allowed to compute the annual average and monthly rainfall, $454.22 \mathrm{~mm}$ and $35.45 \mathrm{~mm}$, respectively. Thus, the Sefrou watershed provides natural water resources and ensures drinking water supply to the inhabitants of the Middle Atlas regions, especially those of Sefrou city. However, regardless of the importance of these resources, the hierarchy of the hydrographic network of this basin (flow network) is poorly developed and branched, which leads to frequent winter floods, constituting a potential risk that can generate human and material damage.

The physiographic characteristics show an elongated relief in the Sefrou watershed by analyzing the water flow indicators. According to the hypsometric curve, the measurements between 500 and 900 m occupy most of the basin's surface (moderate relief). However, based on the overall slope index and the specific gradient, the relief is relatively substantial and decreases towards the basin's outlet (northern part of the study area).

The differences between the eastern and western sides of the drainage system are due to lithology and vegetation cover variations. In addition, the time of concentration is relatively short.

Furthermore, the high volume of these rains and the shortened concentration-time of these surface waters generally generate significant erosion, especially in the marl facies. These results suggest that decreasing the infiltration/runoff ratio is needed. For that, it is necessary to monitor water runoff, protect surface soils from flooding and rapid erosion (by planting trees), and install dikes and small dams to recharge the groundwater in this watershed.

\section{Acknowledgements}

The authors would like to thank the two anonymous reviewers who helped us structure our paper. We also thank: Prof. Dr. Ahmed El Hassani, Resident 
Member of the Hassan II Academy of Sciences and Technology, Morocco, for his support and verification of this paper's scientific background and writing; Prof. Mohamed Chikhaoui, Professor of Agronomy at IAV Rabat, for his critical reading and advice on the formulation of this paper. We thank the Hassan II Academy of Sciences and Technology for its support through the project "Global warming Effects on the Desert landscape of Eastern and Southern Morocco" in which authors participate.

\section{Conflicts of Interest}

The authors declare no conflicts of interest regarding the publication of this paper.

\section{References}

Aboussalam, Z. S., Becker, R. T., Richter, J., Hartenfels, S., El Hassani A., \& Eichholt, S., (2020). The Unique Devonian of Immouzer-du-Kandar (Middle Atlas basement)-Biostratigraphy, Faunas, and Facies Development. Frontiers in Science and Engineering, 10, 127-175.

Agoumi, A., \& Debbarh, A. (2006). Ressources en eau et bassins versants du Maroc: 50 ans de développement (1955-2005).

https://www.oieau.org/eaudoc/system/files/documents/41/206253/206253 doc.pdf

Ahmamou, M. (1987). Étude sédimentologique des calcaires lacustres saïssiens (Plio-Quaternaire) du bassin de Fes-Meknes (Maroc). Thèse 3e cycle, Université Aix-Marseille III.

Beaudet, G. (1969). Le Plateau central marocain et ses bordures. Étude géomorphologique, Rabat (avec carte géomorphologiques au 1/200000 en 4 feuilles) (478 p). Thèse Lettres, Paris,.

Benaabidate, L. (2000). Caractérisation du bassin versant de Sebou: Hydrogéologie, qualité de l'eau et géochimie des eaux thermales. Unpub. Thesis, Faculté des Sciences et Techniques de Fès.

Benshili, K. (1989). Lias-Dogger du Moyen Atlas plissé (Maroc). Sédimentologie, biostratigraphie et évolution palé ogéographique (p. 106). Documents des Laboratoires de Géologie de Lyon.

Bouabid, R., \& Chafai Elalaoui, A. (2010). Impact of Climate Change on Water Resources in Morocco: The Case of Sebou Basin. In A. López-Francos (collab.), Economics of Drought and Drought Preparedness in a Climate Change Context (pp. 57-62). CIHEAM/FAO/ICARDA/GDAR/CEIGRAM/MARM (Options Méditerranéennes: Série A. Séminaires Méditerranéens; n. 95).

Calvet, C. (1979). Interprétation hydrique de la notion d'étage de végétation selon L. Emberger: Application au Maroc (Meteoric Water and Emberger's Vegetation Levels in Morocco). Bulletin de l'Association de Géographes Français, 464, 331-339. https://doi.org/10.3406/bagf.1979.5126

Charrière, A. (1984). Évolution néogène de bassins continentaux et marins dans le Moyen Atlas central (Maroc). Bulletin de la Société Géologique de France, XXVI, 1127-1136. https://doi.org/10.2113/gssgfbull.S7-XXVI.6.1127

Charrière, A. (1989). Carte géologique du Maroc, feuille de Sefrou au 1:100,000ème. Notes et Mémoires Serv. Géol. Maroc, 354. 
Charrière, A. (1992). Évolution paléogéographique méso-cénozoïque du Moyen Atlas (Maroc) en relation avec les domaines atlantique et méditerranéen. Notes et Mémoires Serv. Géol. Maroc, 366, 189-203.

Cirac, P. (1987). Le bassin sud-rifain occidental au Néogène supérieur. Evolution de la dynamique sédimentaire et de la paléogéographie au cours d'une phase de comblement (p. 27). Mémoires de l'Institut de Géologie du Bassin d'Aquitaine.

Coutagne, A. (1954). Quelques considérations sur le pouvoir évaporant de l'atmosphère, le déficit d'écoulement effectif et le déficit d'écoulement maximum. La Houille Blanche, 40, 360-374. https://doi.org/10.1051/lhb/1954036

El Hammichi, F., Benshili, K., \& Elmi, S. (2008). Les faunes d'Ammonites du Toarcien-Aalénien du Moyen Atlas sud-occidental (Maroc). Revue de Paléobiologie, Genève (Décembre 2008), 27, 429-447.

El Hammichi, F., Benshili, K., El Arabi, H., Tabyaoui, H., \& Charrière, A. (2016). L'ammonitico-rosso toarcien de l'Oued Zraa (bordure NW du Moyen-Atlas plissé, Maroc): Études biostratigraphiques, sédimentologiques et cadre paléogéographique. Revue de Paléobiologie, Genève (Décembre 2016), 35, 517-540.

Fedan, B. (1988). Évolution géodynamique d'un bassin intraplaque sur décrochements: Le Moyen Atlas (Maroc) durant le Méso-cénozoïque (338 p). Thèse Sciences, Université Mohammed V de Rabat.

Fedan, B., \& El Hassani, A. (2018). The Jurassic of the Atlas Domain (Morocco). Field Guidebook 10th International Symposium "Cephalopods-Present and Past”. Münstersche Forschungen zur Geologie und Palaeontologie, 110, 119-144.

Fisher, D., \& Pringle III, H. (2013). Evaluation of Alternative Methods for Estimating Reference Evapotranspiration. Agricultural Sciences, 4, 51-60. https://doi.org/10.4236/as.2013.48A008

Giandotti, M. (1937). Idrologia. Barbera Ed., Firenze.

Gourari, L. (2001). Etude Hydrochimique, morphologique, lithostratigraphique, sédimentologique et pétrographique des dépots travetino-détritiques actuels et plio-quaternaires du bassin karstique de l'Oued Aggai (Causse de Sefrou, Moyen-Atlas, Maroc). Unpub. Ph.D. Thesis, Sidi Mohamed Ben Abdellah University.

Gravelius, H. (1914). Grundriss der gesamten Gewässerkunde, Band 1: Fluss künde (Compendium of Hydrology, 1: Rivers, in German) (pp. 265-278). Göschen.

Haan, C. T., Barfield, B. J., \& Hayes J. C. (1994). Design Hydrology and Sedimentology for Small Catchments. Academic Press.

Horton, R. E. (1932). Drainage Basin Characteristics. Eos, Transactions American Geophysical Union, 13, 350-361. https://doi.org/10.1029/TR013i001p00350

Horton, R. E. (1945). Erosional Development of Streams and Their Drainage Basins: Hydro-Physical Approach to Quantitative Morphology. GSA Bulletin, 56, 275-370. https://doi.org/10.1130/0016-7606(1945)56[275:EDOSAT]2.0.CO;2

Jain, S. K., \& Singh, V. P. (2005). Isohyetal Method. In J. H. Lehr, \& J. Keeley (Eds.), Water Encyclopedia. John Wiley \& Sons, Inc. https://doi.org/10.1002/047147844X.me231

Layati, E., Ouigmane, A., Abdelghani Qadem, A., \& El Ghachi, M. (2021). Characterization and Quantification of Meteorological Drought in the Oued El-Abid Watershed, Central High Atlas, Morocco (1980-2019). Hydrospatial Analysis, 5, 45-55.

https://doi.org/10.21523/gcj3.2021050201

Marchane, A., Boudhar, A., Baba, M. W., Hanich, L., \& Chehbouni, A. (2021). Snow Lapse Rate Changes in the Atlas Mountain in Morocco Based on MODIS Time Series 
during the Period 2000-2016. Remote Sensing, 13, 3370.

https://doi.org/10.3390/rs13173370

Martin, J. (1981). Le Moyen Atlas central, étude géomorphologique. Moroccan Series of Notes and Memoirs of the Geological Service of Morocco, 445.

Msatef, K., Benaabidate, L., \& Bouignane, A. (2018). Hydrological and Hydroclimatic Regimes in the Ouergha Watershed. E3S Web of Conferences, 37, Article ID: 04001. https://doi.org/10.1051/e3sconf/20183704001

Naoura, J. (2012). Hydrological and Qualitative Characterization of the Surface Waters of the Upper Inaouene Catchment Area (281 p). PhD Thesis, Faculty of Science and Technology.

Ouzerbane, Z., Boughalem, M., El Hmaidi, A., Aïfa, T., Essahlaoui, A., El Ouali, A., Najine, A., Redouani, F., \& Wafik, A. (2019). Application of GIS to Study the Physiographic Factors and the Water Resources in the Watersheds of Essaouira, Morocco. Journal of Water Sciences \& Environment Technologies, 4, 480-490.

Piedallu, C., Gegout, J. C., Perez, V., \& Lebourgeois, F. (2013). Soil Water Balance Performs Better than Climatic Water Variables in Tree Species Distribution Modelling. Global Ecology and Biogeography, 22, 470-482. https://doi.org/10.1111/geb.12012

Qadem, A. (2015). Quantification, modélisation et gestion de la ressource en eau dans le bassin versant du Haut Sebou (Maroc). Géographie. Université de Lorraine.

Roche, M. (1963). Hydrologie de surface. Gauthier-Villars et ORSTOM, Paris, France.

Sauvage, C. (1960). Le quotient pluviométrique d'Emberger, son utilisation et la présentation géographique de ses variations au Maroc. Annales du Service de physique du globe. Institut Scientifique chérifien Rabat.

Sauvage, C. (1963). «Étages bioclimatiques». Notice explicative; Atlas du Maroc, sect. II; 44 p.; pl. 6b; 1carte au 1/2000000.

Singla, S., Mahé, G., Dieulin, C., Driouech, F., Milano, M. El Guelai, F. Z., \& Ardoin-Bardin, S. (2010). Évolution des relations pluie-débit sur des bassins versants du Maroc. Global Change: Facing Risks and Threats to Water Resources (Proc. of the Sixth World FRIEND Conference, Fez, Morocco, October 2010). IAHS Publication, 340, 679-687.

Smith, K. G. (1950). Standards for Grading Texture of Erosional Topography. American Journal of Science, 248, 655-668. https://doi.org/10.2475/ajs.248.9.655

Strahler, A. N. (1952). Hypsometric (Area-Altitude) Analysis of Erosional Topology. GSA Bulletin, 63, 1117-1142.

https://doi.org/10.1130/0016-7606(1952)63[1117:HAAOET]2.0.CO;2

Termier, H. (1936). Études géologiques sur le Maroc central et le Moyen-Atlas septentrional. Moroccan Series of Notes and Memoirs of the Geological Survey of Morocco, 4, 1566.

Termier, H., \& Dubar, G. (1940). Notice explicative de la carte géologique provisoire du Moyen Atlas septentrional au 1/200,000. Notes et Mémoires Serv. Géol. Maroc, 24 bis.

Thiessen, A. H. (1911). Precipitation Averages for Large Areas. Monthly Weather Review, 39, 1082-1084. https://doi.org/10.1175/1520-0493(1911)39<1082b:PAFLA >2.0.CO;2

Thornthwaite, C. W. (1948). An Approach towards a Rational Classification of Climate. Geographical Review, 38, 55-89. https://doi.org/10.2307/210739

Thornthwaite, C. W., \& Mather, J. R. (1955). The Water Balance (pp. 1-104). Laboratory of Climatology, Publication in Climatology.

Turc, L. (1955). Le bilan de l'eau des sols. Relations entre les précipitations, l'évaporation 
et l'écoulement. INRA.

Turc, L. (1961). Water Requirements Assessment of Irrigation, Potential Evapotranspiration: Simplified and Updated Climatic Formula. Annales Agronomiques, 12, 13-49. 